\title{
Climatic Risk Adaptation Strategies by Smallholder Livestock Farmers in Eastern Amhara Region, Ethiopia
}

\author{
Habtemariam Assefa, Paul Kibwika, Florence Birungi Kyazze, Zeleke Mekuriaw, and Fred Kalanzi
}

\begin{abstract}
The study was conducted to analyze the predominant climatic risks and the strategies livestock farmers used to adapt climatic risks in Eastern Amhara Region of Ethiopia. Cross-sectional research design was used with mixed quantitative and qualitative research approach. The data were collected from 317 livestock farmers using household survey; and FGDs, key informant interviews and personal observation for complementation. The data were analyzed using STATA (version14) and SPSS (version 23) software. The result shows that, $79.8 \%$ of livestock farmers were affected by different climatic risks over the period of 2009-2018. They were affected by drought, animal disease outbreak (ADOB), flood and frost. The percentage of the farmers affected by climatic risks have been fluctuating from year to years but the trends show increased over the last ten years. Every year, $6.7 \%, 6.8 \%, 6.4 \%$ and $3.6 \%$ of livestock farmers were affected by drought, frost, animal disease outbreak (ADOB) and flood, respectively. Seasonally, livestock farmers impacted by drought, flood and frost in autumn, summer and spring, respectively. Animal disease outbreak has occurred in all seasons but higher in autumn. The perception of the farmers was measured based on the frequencies of climatic risks occurrences and the severity level of their impacts. Majority of the farmers perceived that the frequencies of droughts $(49.8 \%)$ and frosts $(43.2 \%)$ increased over the last ten years; whereas flood $(68.8 \%)$ and ADOB $(67.5 \%)$ decreased. The impacts of drought and ADOB were found at moderate level of severity with the value of 2.2 and 1.8 WAI, respectively; whereas frost and flood at lower severity level, which accounts for 1.4 and 1.3 WAI values, respectively. Saving surplus feed $(99.4 \%)$, using modern animal healthcare $(91.8 \%)$, conserving soil and water resources $(\mathbf{7 0 . 8 \%})$ and improving/ customizing animal shelters/shades $(60.3 \%)$; and keeping stress resistance breeds $(\mathbf{5 2 . 7 \%})$ were major strategies for livestock farmers to adapt to climatic risks. These findings imply that drought and ADOB are the predominant climatic risks for livestock farmers in Eastern Amhra Region. Drought majorly occur in autumn; whereas ADOBs occur throughout the year. The farmers also use multiple strategies to adapt to the diverse impacts of the risks. However, the farmers are still vulnerable to the risks and remaining in food insecure. To be the farmers more effective, therefore, the existing adaptation strategies should be supported with science and technology to create stress resistance breeds, improve the quality and availability of feeds and animal health management.
\end{abstract} Wollo

Key words-adaptation, climatic risks, livestock farmer, North

Published on June 25, 2020.

Authors are with the Makerere University, Uganda.

(corresponding e-mail: assefahabtemariam@yahoo.com)

\section{INTRODUCTION}

In Ethiopia, agriculture is the pivotal for the national economic development and provides strategic entry point for poverty reduction and food security among smallholder farmers. It contributes more than $42 \%$ of GDP, $84 \%$ of export earnings and $85 \%$ of total employment [19]. Of which, livestock sub-sector takes $27 \%$ of the total share of agricultural outputs [25] and contributes $40 \%$ of agricultural GDP [12]. And also, it plays an important role in providing export commodities such as live animals, hides, and skins to earn foreign exchanges. Amhara National Regional State, Northern Ethiopia, is endowed with large and diverse livestock resources [18] that provide to smallholder livestock farmers multiple functions like source of cash income, draught power, meat, milk, manure, hides, skins and wool [16]. Livestock also plays a significant role in saving assets, serving as cushion against crop failure, collateral for loan, and social and cultural function for livestock farmers.

However, livestock production in Ethiopia, including Amhara region, has suffered from the effects of climate change due to the ever-increasing weather-related disasters. Climate change had far-reaching consequences on livestock production and reproduction [[52] below3], [[54]5] through creating competition for natural resources, reducing quality feed and water availability [52[51]], increasing incidence of animal diseases [[16]7] and increasing transmission of Zoonotic diseases and migrarting from their original places [[33]4]. In addition, it also amplifies the existing risks and further creates new risks for natural and human systems [[35]6]. Due to climate change. increasing temperature and altering patterns of precipitation in the country causes a frequent occurrence of climatic risks like drought, flood, frost and disease outbreaks. In turn, these oppress agricultural production and increases various agricultural production risks [59], [53[54]]. As the result, smallholder livestock farmers in the country are becoming vulnerable and livestock production is severely affected. Consequently, the impact of climate change remains a major challenge in livestock production of the country. According to MoFED [[45]6], Ethiopia loses annually two to six percent of its livestock production due to the impacts of climate related risks. 
Hence, adaptation appears to be an efficient and friendly way for smallholder farmers to reduce the negative impacts of climate change [[10]1], [38] and enhance their resilience to climatic risks. Adaptation also helps the farmer in managing climatic risks, moderating harms and exploiting beneficial opportunities of climate change [[10]1], [32], [[35]6]. Adaptation strategies in agriculture are based on a combination of specific actions and systemic changes [[21]2]. This can also be applied at different scales; individual/farm, national, or international levels [[10]1] [35]. However, needs are rising to understand location and sector specific adaptation strategies in order to strategically allocate scarce resources for institutional, technological and innovational development under changing climate [[31]2] and also to incorporate climatic risks into local project design and implementation [[55]].

In Eastern Amhara Region, there is a large deficit of information regarding to climatic risks and livestock production. Prior studies in Ethiopia showed that farmers had different adaptation strategies to the impacts of climate change. For example, pastoralist in Afar Region adapted by keeping stress resistance species [[25]6], in southern Ethiopia by adjusting pastoral practices and shifting to non-pastoral livelihoods [11[14]5], in Tigray Region by selling of animals [[22]3], in West Amhara Region by selecting stress resistance breeds [5] and in Central Rift Valley by migrating [[2]]. Others studied the impacts of climate change on the broader livelihood of smallholder farmers and their adaptation strategies [[2]], [[12]], [[20]], [[26]]. Few studies also focused on impacts of climate change on livestock production and reproduction [[27]], feed availability [[9]] and animal health [[1]], [31]. However, these studies failed in addressing the impacts of climatic risks on smallholder livestock farmers, farmers' perception and strategies livestock farmers used to adapt to the risks in Eastern Amhara Region. Adaptation is not generic rather it is location and time specific or contextualized to the available resources, needs, cultural values and perception [[20]], [51] and its effectiveness depends on local institutions and socioeconomic setting of a particular location [[2]], [[44]].

Recently, thus, several scholars give prominence attention to study vulnerability and adaptation strategies at different scales including local, regional and sectoral studies [[44]] to address the location-specific climate related risks and to enhance climate change resilience through research and development interventions [[39]]. Therefore, this study has addressed the identified knowledge gaps through exploring the significant impacts of climatic risks on livestock producers and their strategies to adapt to the risks in Eastern Amhara Region, particularly in North Wollo zone.

Objectives

- To describe the existing climatic risks and their impacts on livestock farmers

- To explore how smallholder livestock farmers adapted to climatic risks using breeding, husbandry and natural resource management strategies

\section{RESEARCH METHODOLOGY}

\section{A. Study Area}

The study was conducted in north Wollo zone, Eastern Amhara Region. North Wollo zone is geographically located between $110 \mathrm{~N}-130 \mathrm{~N}$ and $380 \mathrm{E}$ to $400 \mathrm{E}$. Most of the areas are mountainous and steep slopes. It covers $12,172.50$ square kilometers and its altitude ranges from 600 to 4284 m.a.s.l. North Wollo zone has three agro-ecology zones, namely highland ( $>2500$ m.a.s.l.), midland (1500-2500 m.a.s.l.) and lowland ( $<1500$ m.a.s.l.); and also bi-modal rainfall patterns, such as Belg (short rainy season) from March to May; and Kremt (main rainy season) form mid of Jun to August [[3]]. The area also has four distinct seasons including winter (Bega/ the dry season) from December to February, autumn (Belg/the short rainy season) from March to May, summer (Meher/ the main rainy season) from June to August, and spring (Tseday/ the harvesting season) from September to November. As the result, the Zone has a wide range of annual rainfall (i.e. $600 \mathrm{~mm}$ to $1300 \mathrm{~mm}$ ) and temperature (i.e. $16^{\circ} \mathrm{C}$ to $25^{\circ} \mathrm{C}$ ).

According to 2007 census, the Zone has 1,500,303 populations. Of which, $51 \%$ are male and $49 \%$ are female; and $89.65 \%$ population live in the rural area [[18]]. Their livelihoods depend mainly on a subsistence rain-fed mixed crop-livestock production; and with some off-farm and nonfarm activities. The land holding of the farmers is very small and highly fragmented due to increasing population pressure, natural resource degradation and urbanization. Climate change poses a huge threat to farmers in the area through erratic rainfall, frequent pest and disease incidences, land degradation and water shortages. As a result, the area is grouped among drought prone and food insecure zones in Amhara Region.

\section{B. Research Design}

A cross-sectional survey research design was used with mixed quantitative and qualitative research approaches. Such research design is used to apply when it is needed to study population or subgroup within the population in respect to an outcome and a set of risk factors at a given point in time[[38]]. Multi-stage sampling design was used to select the sample for the survey. The zone was clustered into three agro-ecological zones (i.e. low land, midland and highland) based on its altitude. From each agro-ecological zone, one district was randomly selected to capture the variation attribute to agroecological difference in the study zone. The districts were Habiru from lowland, Gubalafto from midland and Meket from highland. From each selected district, three Peasant Associations (PA), which is the lowest administrative unit, were selected randomly. From each PA, households were selected randomly from sampling frame, which obtained from agricultural development office. The required sample size of the household from each PAs were estimated using the formula of Chand [[19]], which illustrated below (1). Finally, a total of 317 livestock farmers were interviewed for this study. 


$$
\mathrm{n}=\frac{\mathrm{NP}(1-p) x^{2}}{N \cdot e+x P(1-p)}
$$

Where $\mathrm{n}=$ is the sample size, $\mathrm{N}=$ is the population size, $x=$ Confidence level at $95 \%, Z=1.96, P=(P(1-p))$ $=$ Estimated population proportion $(0.5), \mathrm{e}=$ is the precision level at $5 \%(0.05)$.

\section{Data Sources and Collection}

Both quantitative and qualitative data were collected from primary and secondary sources. Primary data were collected from livestock farmers, opinion leaders, experts and administrative bodies. Secondary data were collected from official reports from Government and Non-government organization. Household survey was conducted to collect the quantitative data at the community level. In this regards, pretested semi-structured questionnaire was used. Training was given to enumerators in order to familiarize and have a common understanding to questions. Finally, data collection was embarked from March to April, 2019.

Moreover, Focus Group Discussions (FGDs), Key Informant (KI) interview and personal observation were also used to get in-depth understanding and to complement the responses from the household survey. Three FGDs were conducted, one from each agro-ecology zone. Each FGD comprised 10 participants from elders, youth and women to include the opinion of all social classes. The sessions were moderated using a checklist in collaboration to PA's development agent. Consent voice recording was used to assist the data collection. Furthermore, KI interviews were carried out with different individuals. The interviews were made with elders, community leaders, development agents; and experts from Livestock Development Agency, Safety Net program, Disaster and Risk Prevention program at district, zonal and regional levels; and also experts from NGOs (Organization for Rehabilitation in Amhara, Den Sectors, Save the Children and World vision) and researchers from Srinka Agricultural Research Center and Woldia University. Personal observation was also made at farm level to confirm the actual usage of adaptation strategies by livestock farmers.

\section{Data Analysis}

Both descriptive and inferential statistics were used to analyze the data collected from household survey, while thematic analysis was used for qualitative responses from the FGDs and Key Informant interviews. The analysis was begun by measuring the impacts of climatic risks on livestock farmers based on climatic risks rends, seasonal distribution and observed impacts over the period of 2009 to 2018. The threepoint scale-Liker and Weighted Average Index (WAI) were used to measure farmers' perception in terms of frequencies of the risks and the severity levels of their impacts. Regarding WAI, respondents were allowed to weigh the severity level of the impacts by scoring value one, two and three for low, moderate and high severity levels, respectively. This index was computed using (2) [[46]]. STATA (version 14.1), SPSS (version 23) and Microsoft Excel were used to analyze the quantitative data.

$$
\mathrm{WAI}=\frac{\mathrm{F} 2 \mathrm{~W} 2+\mathrm{F} 1 \mathrm{~W} 1+\mathrm{F} 0 \mathrm{~W} 0}{\frac{\mathrm{F} 2+\mathrm{F} 1+\mathrm{F} 0}{\sum F i W i}} ;
$$$$
\mathrm{WAI}=
$$

Where: $\mathrm{F}=$ frequency; $\mathrm{W}=$ weight of each scale; $\mathrm{i}=$ weight $(3=$ high; $2=$ moderate and $1=$ low $)$

\section{RESULT AND DISCUSSION}

\section{A. Climatic Risks and their Impacts on Livestock Farmers}

Trend of climatic risks: Livestock farmers in North Wollo Zone were challenged with various climate related risks. Table I shows that from 2009 to $2018,79.8 \%$ of livestock farmers were adversely affected by different climatic risks. The chisquare value at statistically significant level $(p<0.01)$ implies that livestock farmers in north Wollo zone had a higher probability level to be negatively affected by climatic risks.

TABLE I: LIVESTOCK FARMERS AFFECTED BY CLIMATIC RISKS (2009-2018)

\begin{tabular}{|l|c|c|c|c|}
\hline Variable & Cases & $\begin{array}{c}\text { Percentage } \\
(\mathrm{n}=317)\end{array}$ & $X^{2}$ & $\begin{array}{c}\text { Sig. } \\
\text { value }\end{array}$ \\
\hline \multirow{2}{*}{$\begin{array}{l}\text { Affected } \\
\text { farmer }\end{array}$} & Yes & 79.8 & \multirow{2}{*}{112.65} & \multirow{2}{*}{0.00} \\
\cline { 2 - 3 } & No & 20.2 & & \\
\cline { 2 - 3 } & Total & 100.0 & & \\
\hline
\end{tabular}

Drought, flood, frost and animal disease outbreak (ADOB) were commonly mentioned climatic risk for livestock farmers in North Wollo Zone. Fig. 1 show that the anomalies of the percentage of the farmers affected with climatic risks over the period 2009 to 2018 in north Wollo zone. The graphs revealed that the percentages of the affected farmers by the risks were fluctuated with increasing trends. Over the mentioned period, it was estimated that $6.7 \%, 6.8 \%, 6.4 \%$ and $3.6 \%$ of livestock farmers were annually affected by drought, frost, ADOB and flood, respectively. The impact of drought over livestock farmers have significantly fluctuated as compared to the rest of climatic risks. The lowest and highest percentages of the affected farmers by drought were $2.3 \%$ in 2010 and $12.6 \%$ in 2015. Participants in the FGD agreed that there was no a defined average year in precipitation and temperature for the last ten or more years. Some year has become warmer or colder, wetter or drier, than others. Thereby, farmers have been confused to pretend and prepare themselves to the risk.

The percentage of affected farmers by droughts and floods started exceeding the estimated annual percentage of the affected farmer since 2013 and 2012, respectively (Fig. 1, (a) $\&(d))$. This implies that livestock farmers in the study zone had relatively longer experience with the effects of droughts and floods than frosts and ADOBs. This was confirmed by the existing development programs of most government and nongovernment organizations in north Wollo zone. Their programs have directly or indirectly focused in addressing drought and flood related problems mainly through safety-net and natural resource management programs. The result of current study 
agreed with the report from south-western Ethiopia, the magnitude, duration and occurrence of droughts varied and rapidly increased over time from 1983 to 2016 [[10]]. It was also projected that the occurrence of drought and flood will be increasing in Ethiopia due to the increment of inter-annual variability of precipitation and temperature [[36]].
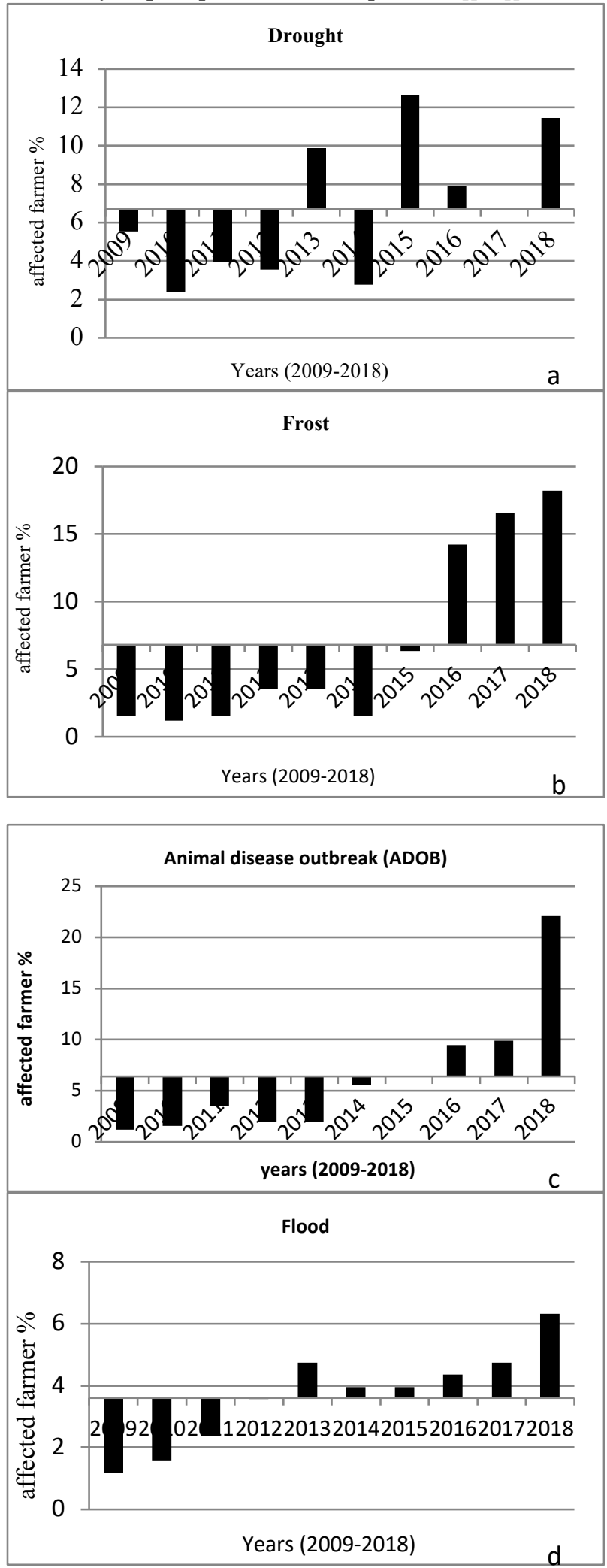

Fig. 1. Percentage of affected farmers by climatic risks (2009-2018).

Seasonal distribution and observed impacts: As indicated in research methodology section, the study zone has four climatic seasons, namely summer, spring, winter and autumn. Accordingly, the occurrences and the level of impacts of climatic risks also varied. Understanding this variation allows the farmers to gain a better knowledge on the magnitude of the changes in production levels under climate risks and to make a decision to choose particular adaptation strategies [62[61][61]]. Seasonal distribution of climatic risks and average animal death due to the impact of the risks per household are presented in Fig. 3 and Table 5, respectively.

Most livestock farmers were affected by drought in autumn $(84.22 \%)$ and considerably in summer $(41.96 \%)$ and winter (41.64\%). The current result agreed with reports from Southwestern Ethiopia [[9]]. From FGD and Key Informant discussion, drought occurs in north Wollo zone when the rain starts late and stops early or no rain at all during the main rainy season i.e. in summer. This leads to shortage of green fodder to their animals in summer; and difficult to collect adequate hay and crop residues in spring season to feed in winter and autumn, where feed is deficit. Besides, drought has adversely affected the availability and quality of water in the study zone. Most waterbodies get dry and become a good fertile ground for multiplication of water borne pathogens. Thereby, animals were highly vulnerable to various diseases and parasites like leeches and ticks. As the result, livestock farmers have costed in many ways, such as livestock death, milk reduction, loss of draught power and incur extra feed costs. Due to droughts from 2014 to 2018 , a farmer has lost $41.0 \%$ of cattle, $32.0 \%$ of shoat and $66.7 \%$ of equine from the total flock size through deaths (Table II). Reference [49] shows, due to the delay of rainfall in the year 2013, 246 cattle, 26 equines, 158 shoats and 2 camels died; and 1922 cattle, 370 shoats, 117 equines and 16 camels were severely affected by the drought only in lowland part of the study area. In addition, farmers were also forced for unintended selling of their animals with very less marketing prices. Participants in FGD also mentioned that one local breed in calf cow was sold by 60-125 USD during drought season, which would be sold by 416 USD in normal situation. In turn, all these played significant roles in aggravating the existing food insecurities, poverty and rural-to-urban migrations in the study zone.

Moreover, droughts also caused migration of large number of animals from neighboring region (i.e. Afar Region) into the study zone, specifically into Raya Koba, Gubalafto and Habru districts. They migrated into the study zone on December and stayed in up to March to April. North Wollo Zone Disaster Risk Management Projects coordinate office [50] reported that due to the drought of 2012, 303206 cattle, 56700 camels and 52533 shoats migrated into the zone; and created competition in utilizing pasture and water resources and caused various animal diseases outbreaks like Contagious Bovine Pleuropneumonia (CBPP), Contagious Caprine Pleuropneumonia (CCPP), Foot and Mouth disease, sheep and goat Smallpox, Anthrax and 
Pastreullosis. In the same year, 554 cattle, 799 shoats and 176 camels sick; and 148 cattle, 405 shoat and 29 camels died due to the outbreak of diseases in the areas.

In north Wollo zone, flood mostly occurred in summer season, where rainfall is long and excessive in all places. In autumn, heavy but short rainfall also occurred in highlands of the zone which created a devastative flood for lowlanders. The ridged topography of the zone also made livestock farmers more vulnerable to floods and landslides. According to the participants in FGD, flood affected livestock farmers through animal death and incurring extra feed costs due to devastative damages on cropland, grazing land and washing away of live animals in time of heavy rains. A farmer lost $25.4 \%$ cattle, $28.7 \%$ shoat and $66.7 \%$ equine due to the floods from 2014 to 2018 (Table II). As indicated in [[47]], Habru, Raya Kobo, Gubalafto, Wodla, Delanta and Lasta districts, and over 112,000 populations and 12,400 ha of farmland were vulnerable to flood in the North Wollo Zone.

Regarding animal disease outbreaks, livestock farmers were affected across all seasons but more in autumn. This attributed to higher temperature and humidity and sever feed shortage in autumn. The types erupted disease have varied by seasons and livestock species. The common outbreak disease in autumn season were Foot and Mouth disease, Fasciolosis, Lung worm, Gastro-intestinal Nematodes for calf and sheep, and Nematodes for horse; in summer was African horse sickness; in spring were Pestes des Petitis Rumniatus, Sheep and Goat pox; and in winter season were Lumpy skin disease, Anthrax, Black leg, Pastreullosis [[47]]. Similarly, Solomon and Firew reviewed that emerging, spreading and distributing of livestock disease outbreaks were affected by seasons and long-term climate changes [[54]]. This was because the changes in temperature and rainfall pattern alter the rate of pathogen development, distribution of disease vectors and rate of disease transmission between hosts [[1]].

According to participants in FGD, animal death, shortage of draught power and incurring extra health cost were the major impacts of animal disease outbreak to livestock farmers in the study zone. Within five years, a farmer lost $78.3 \%$ of cattle, $40.6 \%$ of shoat and $8.5 \%$ of equine due to animal disease outbreaks (Table II). In turn, all these contribute a significant loss in livestock production at the household and regional level. In every year, Amhara Region has lost 30\%-50\% livestock production due to animal disease outbreaks [[5]].

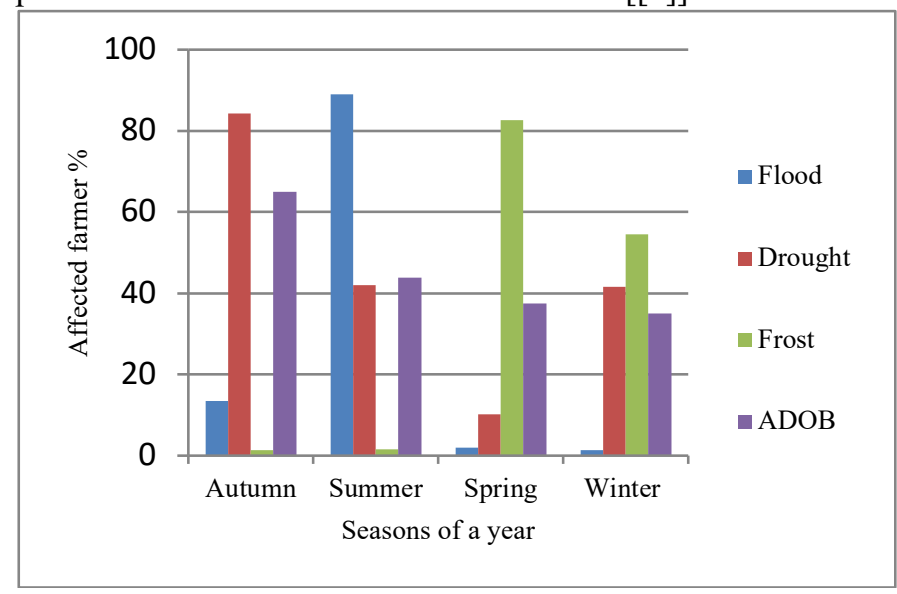

Fig. 2. Seasonal distribution of climatic risks occurrence

In study zone, as shown in Fig. 2, frost occurred in spring and winter seasons and affected large percentage of livestock farmers. The results of FGD and Key informant interview revealed that frost mostly occurred only for two or three consecutive days in a season, but it brought long lasting impacts on livestock production, animal health and fodder availability. When surrounding temperature get cooler, the problem of hypothermia (i.e. body temperature drops below the normal) occurs on animals and caused damage in fodder production and hazards for using some forages [[57]]. As the result, livestock farmers have incurred extra cost for feed and healthcare and reduced production of milk, meat and draught power.

TABLE II: AVERAGE ANIMAL DEATH PER HOUSEHOLD BY RESPECTIVE CLIMATIC RISK AND THEIR PERCENTAGE FROM TOTAL HERD BETWEEN YEAR 2014 \& 2018

\begin{tabular}{|c|c|c|c|c|c|c|c|c|}
\hline \multirow{2}{*}{ Species } & \multicolumn{8}{|c|}{ Climatic risk types } \\
\hline & Mean (SD) & Percentage & Mean (SD) & Percentage & Mean (SD) & Percentage & Mean (SD) & Percentage \\
\hline Cattle & $2.5(1.6)$ & 41.0 & $2.1(1.8)$ & 42.3 & $1.6(1.1)$ & 25.4 & $2.3(1.3)$ & $32.0 \%$ \\
\hline Equine & $1.4(0.6)$ & 66.7 & $2.0(1.0)$ & 86.1 & $1.0(0.0)$ & 66.7 & $1.0(0.0)$ & $66.7 \%$ \\
\hline
\end{tabular}

\section{B. Farmers' perception on climatic risks}

Perception is a necessary prerequisite for climate change adaptation because it motivates a farmer to make decision in adapting to the risks of climate change[[60]], [[55]]. For the current study, the perception is discussed based on frequency of climatic risks occurrence and severity levels of their impacts on livestock farming.

Perception on climatic risks Frequency: Farmers' perception on the frequency of climatic risks occurrence over the period of 2009 to 2018 in North Wollo zone is illustrated in Table III. Most livestock farmer have perceived that the frequency of drought (49.8\%) and frost $(43.2 \%)$ have increased; whereas flood (68.8\%) and animals disease outbreak $(67.5 \%)$ decreased over the last ten years. The proportions of variation across the three perception categories of the risks are statistically highly significant at $1 \%$ level of significance $(\mathrm{P}<0.01)$. Participants in FGD also have agreed with this result. They sensitized that before one or two decades, the rainfall pattern of the area was bimodal, such as short rainfall from 
March to April and long rainfall from mid-June to August. Accordingly, farmers could harvest short and long maturing crops, which sourced cop residues to their animals. Overtime, this rainfall pattern changed into almost unimodal, erratic and short rainfalls from the mid-July to mid-August. As the results, droughts in the study zone frequently occurred; and the availability of feed became a serious problem for livestock farmers. Currently, the price of feed is higher than that of food grains. Farmers in Central Rift Valley and Southern Ethiopia also perceived that drought became more frequent and increased its coverage in their area from year to year [[2]], [[13]]. Farmers in northern Ethiopia also noted that their surrounding temperature increased and the amount of rainfall declined over the last 30 years, which resulted in recurrent droughts in their areas [[52]].

TABLE III: PERCEIVED FREQUENCY OF CLIMATIC RISKS OCCURRENCE OVER THE PERIOD OF 2009 TO 2018

\begin{tabular}{|c|c|c|c|c|c|}
\hline \multirow[t]{2}{*}{ Climatic risks } & \multicolumn{3}{|c|}{ Trends } & \multirow{2}{*}{$\begin{array}{l}\text { Chi- } \\
\text { square }\end{array}$} & \multirow{2}{*}{$\begin{array}{l}\text { Sig. } \\
\text { value }\end{array}$} \\
\hline & Increasing & Decreasing & No change & & \\
\hline Drought & 49.8 & 39.1 & 11 & 76.4 & 0.00 \\
\hline Flood & 15.1 & 68.8 & 16.1 & 179.2 & 0.00 \\
\hline $\begin{array}{l}\text { Animal disease } \\
\text { outbreak (ADOB) }\end{array}$ & 28.4 & 67.5 & 4.1 & 194.7 & 0.00 \\
\hline
\end{tabular}

According to the result of FGD, the frequency of frost was not uniform in all places of the study zone. Farmers from the highland have believed that the frequency of frost decreased and the environment became warmer, whereas in midland and lowland areas it increased, particularly from October to December and in January. They also added that before one to two decades, frosts occurred in every 10 years but recently it occurred in every three years.

Decreasing the frequency of floods and animal disease outbreaks was resulted from widely practicing of soil and water conservation and animal health services expansion in the study area, respectively. Before 2015, livestock farmers were expected to travel $10 \mathrm{~km}$ with their sick animals to get veterinary clinic. This was because the health extension package of the region allowed one veterinary clinic to give a service for the household within $10 \mathrm{~km}$ radius. In practical, one clinic for three Peasant Associations (PAs). Currently, in Growth and Transformation Program-II, the package has been changed into one veterinary clinic for each PA [[6]]. This helped the farmers to access animal clinic at their PA though it is hard to say all clinics are full-fledged with laboratories, drugs and experienced manpower to give all the necessary services.

Perception on Severity Level of the Impacts: The decision behavior of a farmer in choosing certain adaption strategies for a particular climatic risk can be influenced by farmer's perception on the impact severity level of the risks. The study used Weighted Average Index (WAI) to measure the severity levels of the impacts on livestock productions. The severity levels were grouped into three categories such as low, moderate and high levels, where their WAI value is between 1-1.6, 1.612.28 and 2.29-3, respectively. The result of WAI is presented in Table IV. The result revealed that the impacts of drought and animal disease outbreak on livestock production were found at moderate level of severity, which account for 2.2 and $1.8 \mathrm{WAI}$ values, respectively; whereas the impacts of frost and flood were lower severity level with the values of 1.4 and $1.3 \mathrm{WAI}$, respectively.

DOI: http://dx.doi.org/10.24018/ejfood.2020.2.3.62
TABLE IV: WEIGHTED AVERAGE INDEX FOR THE SEVERITY OF CLIMATIC RISKS OVER 2009 TO 2018

\begin{tabular}{|l|l|l|l|l|l|}
\hline \multirow{2}{*}{ Climatic risks } & \multicolumn{3}{|l|}{ Frequency of severity levels } & \multirow{2}{*}{ WAI } & \multirow{2}{*}{ Rank } \\
\cline { 2 - 4 } & Low & Moderate & High & & \\
\hline Drought & 107 & 35 & 169 & 2.2 & $1^{\text {st }}$ \\
\hline Disease outbreak & 151 & 130 & 267 & 1.8 & $2^{\text {nd }}$ \\
\hline Frost & 212 & 69 & 24 & 1.4 & $3^{\text {rd }}$ \\
\hline Flood & 244 & 35 & 26 & 1.3 & $4^{\text {th }}$ \\
\hline
\end{tabular}
severity level of the impact is low, moderate and high, respectively.

However, farmers in the FGD farmers put the impact of frosts in the second rank, next to drought, in moderately affecting livestock farmers. Their rationales were frost has long lasting negative impacts on fodder and crop production and physiology and metabolic functions of the animals. With regards to ranking, drought took the $1^{\text {st }}$ rank in adversely affecting livestock farmers, and followed by animal disease outbreaks. Frost and flood were the $3^{\text {rd }}$ and $4^{\text {th }}$ ranked for livestock farmers in north Wollo zone.

\section{Adaptation Strategies}

In smallholder agriculture, adapting to hazards of climate change is fundamental to reduce rural vulnerability, maintain health ecosystem and improve agricultural productivity and income of the farmers [[10]]. In the study area, with different level of awareness, livestock farmers used different strategies to adapt to climatic risks. The strategies are discussed below on the base of breeding, husbandry practices and natural resources management strategies.

Breeding Strategy: In north Wollo zone, keeping stress resistance breeds $(52.7 \%)$ was one of the major adaptation strategies to livestock farmers used (Table V). The strategy was used for both cattle and small ruminants to adapt to drought and animal disease outbreaks (ADOB). The farmers used both animal selection and crossbreeding as major breeding strategies to improve the genetic potential of their local breeds. Most livestock farmers (68.2\%) selected genetically potential animals from their local herds based on important superior traits, such as efficient feed utilization, disease tolerance,

Vol 2 | Issue 3 | June $2020 \quad 6$ 
mothering ability, strong draught power and better physical conformation. The common local breeds were Wollo Highland Zebu in the highland, Raya breed in the lowland; and few Afar bread in the lowland areas bordering with Afar region in cattle production [[56]]; and black Wollo highland and Afar breed types in sheep production [[28]] and central highland breed in goat production. These local breeds easily adapt to harsh climatic conditions, utilize limited and poor-quality feed resources and tolerate a range of diseases [[42]].

Crossbreeding was done by the farmers either through crossing the breeding cow with the selected local breeds $(57.2 \%)$ or exotic breeds (39.9\%). Mostly, the former one was done using bull service, which were sourced from either own or neighbors/friends.; whereas the later one was done using Artificial insemination (AI). In some places, community bull or ram services were also used for crossbreeding. Jersey and Holliston Frisian breeds were the preferred breeds for crossing in cattle production, while Awassi, Washera and Tumelie (a cross of Wollo highland sheep with Afar sheep types) breeds in sheep production.

Keeping these stress resistance breeds helped livestock farmers to continue in livestock production under limited and poor-quality feed and water resources; and able to produce better animal products and fetch better incomes. In addition, it reduces the cost of livestock production to the farmers through minimizing the cost of feed and animal healthcare. Prior studies also reported that livestock farmers adapted to the effects of climate changes through improved breeding strategies [[61]], [[42]].

Livestock husbandry management: Changing livestock production system help the farmer to adapt the effects of climate change [[61]]. Hence, livestock farmers in north Wollo zone need to use effective husbandry practices to manage climatic risks. The major husbandry strategies are discussed in terms of managing herd composition, feeding and natural resource.

a) Herd composition management: Reducing the size of the herds $(38.8 \%)$ and keeping stress resistance species (35.3\%) were important adaptation strategies among herd composition management to livestock farmers in the study area (Table V). Reducing herd size was mainly used to adapt the effects of drought; whereas keeping stress resistance species was used for adapting to droughts, ADOBs and frosts. Before ten years, a farmer who adapted by herd size reduction had been raising on average up to six cattle, ten shoats and two equines. Due to increasing feed shortage associated to recurrent droughts and frosts, the farmers reduced the herd size to three cattle, three shoat and one equine on average (Table V). Once the herd size determined, farmers have kept selling young and old animals in regular basis to maintain the size.

In keeping stress resistance livestock species, farmers have shifted from keeping all species into only cattle and considerably horse in the highland and camel in the lowland areas. As indicated in Table V, significant percentages of the farmers have stopped from rearing mule $(100 \%)$, goat $(87.9 \%)$; and considerably from sheep (51.6\%) and donkey (50.0\%) comparing to ten year before. The farmers argued that most disease outbreaks in study zone attacked more small ruminants and a severe feed shortage for all livestock species. As the result, farmers were forced to keep cattle and equines for draught power, milk production and transport purposes. In most developing countries, livestock farmers adapted to climate change by keeping stress resistance livestock species [[32]]. Furthermore, some farmers also adapted to climatic risks by adjusting reproduction season of their animals. This strategy was used for cattle production to adapt mainly to droughts and frosts. The farmers preferred their animals to give birth in a good season, from July to August, where green pasture is adequate and ambient temperature is better for milking cows and calves. All these strategies enabled livestock farmers to utilize effectively the available feed resources, manage their herds with less manpower, produce better milk and meat yield and reduce animal death due to feed shortage during drought period. And also, it reduced the workloads of the farmers in searching of feeds and water resources.

b) Feed and feeding managements: Livestock farmers in north Wollo zone have also adapted to climatic risks using various feed and feeding practices. As indicated in Table V, saving surplus feed resources $(99.4 \%)$ was the most dominant adaptation strategy that livestock farmers used for drought and frost. Various feed resources were collected during surplus period - hay from October to November and crop residues from November to January. For their cattle, crop residues - like stover, straw and bran - were collected from sorghum, teff, barley, wheat, oat (Aja), grass pea and green mung bean (Masho). Grass for hay making was also harvested from pasture lands, boundary of cropland, hillsides and compounds of rural institutes (i.e. school and church). The farmers stored these feeds out of the reach of too much sunshine, moisture and termites to stay longer with their quality; and used as major feed during drought and frost seasons. In addition, farmers also use industrial byproducts (i.e. wheat bran, noug seed cake and lentil hull) and collect seed pods and leaves from Tree Lucerne and Sasbania in the normal seasons to feed their sheep during feed shortage seasons. while tree fruits and leaves from Girar (Acacia Abyssinica) and Kurkura (Ziziphus spina-christi) were collected for their goats. This strategy made livestock farmer more effective in minimizing feed wastage, extended feed availability, reduced animal death and unintended animals selling due to feed shortage and minimized feed cost and migration. In Afar Region [[54]] and Central Rift Valley of Ethiopia [[2]], farmers also used saving various crop residues as a major adaptation strategy to the effects of drought; while in Arsi zone, concentrate was supplemented during drought season [[23]].

Selective feeding (40.1\%) was another important adaptation strategy in the study zone. It was used to minimize the adverse impacts of droughts. The farmers provide the available feeds selectively to oxen and milking cows during drought seasons. This is because oxen should not loss their power to plow in the

Vol 2 | Issue 3 | June $2020 \quad 7$ 
next cropping season and cows should nurture their calves. This feeding strategy helped the farmers to be effective in utilizing the scars feeds, timely plowing their croplands and easily restocking their cattle production. Some farmers (38.8\%) further use indoors feeding as adaptation strategy to the effects of drought and disease outbreaks. Animals were not allowed to move long distance for grazing and watering rather they were provided all necessary feed and water at their homestead. They moved briefly in morning and evening to get breath and to drink water from nearby water sources. The strategy was very important to the farmers to keep small number but more productive animals with less manpower, prevent the spread of diseases and improve milk and meat yield and generate better income. In addition, it also played a significant role in sustaining the physical structures of soil and water conservations, reducing deforestation and accessing larger volume of manure for compost and biogas preparation. Somehow, the current study agreed with Asmare \& Meheret [[7]], who reported that indoors feeding significantly contributed in promoting improve forage development, stallfeeding and zero grazing which resulted in reduced land degradation and soil erosion in Bahir Dar Zuria district.

Few livestock farmers $(13.9 \%)$ grow improved forage as a major adaptation strategy to the effects of drought. Cowpea, Lablab, Oat, Napier grass, Pigeon pea, Tree Lucerne and Sasbania were the common improved forage grown in study zone. They were grown at the boundaries of irrigated crops, along the physical structures of soil conservation, backyards and intercropping. This help the farmers to access green and nutritious fodder to their animals and produce better milk and meat yield in drought season.

c) Animal Healthcare and Housing: Different housing and health management practices were used to adapt the effects of disease and frosts in the study zone. As indicated in Table V, using modern healthcare $(91.8 \%)$ was the most important adaptation strategy to livestock farmers in the study zone. Vaccination, de-worming and treatment were the modern healthcare strategies given to their animals. Vaccination was given before and after the main rainy season (i.e. Jun-August) to African horse sickness, anthrax, blackleg, pastuerolosis, sheep and goat pox, lumpy skin disease and pestes des petitis rumniatus. While strategic de-worming was given from September to January to control fasciolosis, lungworm, gastrointestinal and nematodes; and strategic spraying from March to Jun to external parasites; and treatment was given at any time. This adaptation strategy has brought a significant change in reducing the eruption and the spread of contagious disease and consequently animal deaths; and improving livestock production. Some livestock farmers $(20.2 \%)$ further use traditional animal healthcare to adapt to the effects of animal disease outbreaks.

Moreover, livestock farmers also use improved housing/shading (60.3\%) practices as a major adaptation strategy to animal disease outbreaks and frosts. Since the past ten years, the open barn housing of the small ruminant was changed into thatched housing to protect them from extreme sunshine and cold temperature. For large animals, livestock farmers use independent housing i.e. separated from the family living. The farmers can customize the house based on the surrounding temperature to avoid heat and cold stresses. In addition, they construct shades from locally available materials or planting trees to protect their animals from excessive sunshine and heat weaves. As insulation, they leave animal dungs over the floor of the shade to maintain heat during frost season. Animals were not also released for grazing before the area get warmer to avoid cold stress; and stayed under shades in daytime to prevent from sunshine and windstorms. According to farmers, all these resulted in reduced the prevalence of animal diseases and consequently reduced mortality rate of milking cows, ewes, does, weak and young animals; and improved milk and meat yields. Since most houses were constructed with relatively good feed trough, wastage of feed and soil born disease were also minimal.

Natural resources manage : A proper managing and utilizing of natural resources plays a significant role in building climate change resilience of smallholder farmers [[1]]. Hence, livestock farmers in north Wollo zone need to use efficient strategies in utilizing their key natural resources - soil, water and vegetation - to reduce their vulnerability to climatic risks.

Table $\mathrm{V}$ show that practicing soil and water conservation $(70.8 \%)$ was also one of the major strategies for livestock farmers in adapting to droughts and floods. In 2010, Ethiopian government launched a land restoration program to double agricultural production through proper use of natural resources and agricultural lands [[24]]. Since then, various soil and water conservation activities were widely promoted in the country, particularly in the highland areas. Livestock farmers in north Wollo zone also involved in constructing different physical structures on their farmlands and protected areas. The common physical structures were bench bunds, stone faced soil bunds, hillside terrace, stone bund, check dams, fanya juu, half-moon and trenches depend on the slope of the land, soil types and land use. They were constructed collectively by mobilizing the community. Grasses (i.e. vetiver, napir grass, desho grass), legumes (cowpea, lablab and desmodium) and multipurpose fodders (sasbania, pigeon pea and tree lucerne) were planted to substantiate the physical structures.

In addition, tree plantation (61.7\%) was used as a major adaptation strategy to the effects of droughts and floods in the study zone. Livestock farmers planted different locally adapted trees species on their private and communal lands. The common species were Juniperus procera $(T s i d)$, Cordia Africana (Wanza), Acacia abyssinica (Girar), African Olive (Woira) and Eucalypts (Bair zaf). Both strategies have brought significant changes in reducing soil erosion and unintended flooding, improving soil fertility, prolonging the existences of 


\begin{tabular}{|c|c|c|c|}
\hline Strategies & $\begin{array}{l}\text { Percentage } \\
(n=317)\end{array}$ & Aims & Application \\
\hline \multicolumn{4}{|l|}{$\begin{array}{l}\text { Breeding } \\
\text { management }\end{array}$} \\
\hline $\begin{array}{l}\text { Keeping stress } \\
\text { resistance breeds }\end{array}$ & 52.7 & $\begin{array}{l}\text { Adapt to } \\
\text { drought \& } \\
\text { ADOB }\end{array}$ & $\begin{array}{l}\text { Genetic improvement via: } \\
\text { - Selection from own herds ( } 68.2 \%) \text {; based on important } \\
\text { traits; Common local breed: Wollo Highland Zebu, Raya } \\
\text { \& Afar breads for cattle; black Wollo highland and Afar } \\
\text { sheep for sheep; and central highland breed for goat. } \\
\text { - Local X selected local breed (57.2\%); done by bulls, } \\
\text { sourced either from own or friends } \\
\text { - Local X exotic breed ( } 39.9 \%) \text {; crossbred bull or AI; } \\
\text { breeds: Jersey and Holliston Frisian for cattle \& Awassi, } \\
\text { Washera and Tumelie for sheep }\end{array}$ \\
\hline \multicolumn{4}{|l|}{$\begin{array}{l}\text { Livestock husbandry } \\
\text { management } \\
\text { a. Herd composition } \\
\text { management }\end{array}$} \\
\hline $\begin{array}{l}\text { Adjust reproduction } \\
\text { season }\end{array}$ & 27.1 & $\begin{array}{l}\text { Adapt to } \\
\text { drought \& } \\
\text { frost }\end{array}$ & $\begin{array}{l}\text { Planned the breeding season of the animal to give birth at } \\
\text { good season. From March to Jun and October to January } \\
\text { were bad seasons due feed shortage and cold stress. July \& } \\
\text { August were good season where feed is adequate and } \\
\text { weather is better to milking cows and calves. }\end{array}$ \\
\hline $\begin{array}{l}\text { Rearing stress } \\
\text { resistance livestock } \\
\text { species }\end{array}$ & 35.3 & $\begin{array}{l}\text { Adapt to } \\
\text { drought } \\
\text { \&ADOB }\end{array}$ & $\begin{array}{l}\text { Before one to two decades, all species were reared. } \\
\text { Currently, most farmers have relay on specific species. } \\
\text { Percentages of farmer dropout from rearing cattle, sheep, } \\
\text { goat, donkey, horse, mule \& camel were } 6.5 \% \text {, } 51.6 \% \text {, } \\
87.9 \%, 50.0 \%, 23.1 \% \text {, } 100 \% \& 33.3 \% \text {, respectively. The } \\
\text { higher the percentage, the more dropout of the farmer from } \\
\text { rearing a species due to their less stress resistance. }\end{array}$ \\
\hline Diversify herd species & 3.8 & $\begin{array}{l}\text { Adapt to } \\
\text { drought }\end{array}$ & $\begin{array}{l}\text { Diversified from rearing of cattle, sheep and camel to all } \\
\text { species except mule }\end{array}$ \\
\hline $\begin{array}{l}\text { Reduce livestock herd } \\
\text { size }\end{array}$ & 38.8 & $\begin{array}{l}\text { Adapt to } \\
\text { drought }\end{array}$ & $\begin{array}{l}\text { Before ten years, a farmer kept in average six cattle, ten } \\
\text { shoats \& two equines; Due to increasing feed shortage, a } \\
\text { farmer reduced the size into in average three cattle, three } \\
\text { shoats and one equine by culling/selling low productive } \\
\text { animals and then maintain its size by continuously selling } \\
\text { younger and older animals }\end{array}$ \\
\hline
\end{tabular}

b. Feed and feeding management

Indoors feeding

Adapt to drought \& $\mathrm{ADOB}$

Producing improved forage

13.9 Adapt to drought

Saving surplus feed resources

Adapt to drought and frost

Selective feeding

c. Animal healthcare and housing Improving/customizing animal shelter and shade

\section{Used for}

Observed benefits

(species)

$\begin{array}{ll}\text { Large } & \text { Keep involving in } \\ \text { ruminant } & \begin{array}{l}\text { livestock rearing under } \\ \&\end{array} \\ \text { limited resources, } \\ \text { Small } & \text { reduced cost of feed and } \\ \text { ruminant } & \text { healthcare increased } \\ & \text { yield in meat, milk and } \\ & \text { hair \& generate better } \\ & \text { income }\end{array}$

Large ruminate

Reduced the mortality rate of milking cow and calf, improved milk production \& reduces the workloads in searching of feeds and water

Large ruminant

Reduced the rate of animal mortality due to disease and feed shortage \& improved productivity

Minimized the risks of animal and production loss

Large Small six months, needed less ruminant manpower, produced better yields \& income; $\&$ reduced animals death

$\begin{array}{ll}\begin{array}{l}\text { Large } \\ \text { ruminant } \\ \text { \& sheep }\end{array} & \begin{array}{l}\text { Needed less manpower, } \\ \text { reduced disease } \\ \text { dissemination \& } \\ \text { increased production }\end{array} \\ \begin{array}{l}\text { Large } \\ \text { ruminant }\end{array} & \begin{array}{l}\text { Accessed green and } \\ \text { nutritious fodders } \\ \text { d smang drought period; } \\ \text { ruminant } \\ \text { increased milk and meat } \\ \text { production }\end{array} \\ \text { All } & \begin{array}{l}\text { Reduced feed shortage, } \\ \text { reduced animal death, } \\ \text { unintended animals }\end{array} \\ & \text { selling, feed cost and } \\ \text { migration }\end{array}$

Large Timely plowed land and ruminant easily restocked

\section{Large Reduced disease ruminant incidences, improved \& small yield, reduced animal ruminant death and minimize feed wastage}
Adapt to ADOB \& frost
Built thatched house for small ruminants and independent hot season large animals. The houses were ventilated in from locally available materials and planting trees; \& also left animal dung over the floor of the shade to create warm to animals 


\begin{tabular}{|c|c|c|c|c|c|}
\hline Strategies & $\begin{array}{c}\text { Percentage } \\
(n=317)\end{array}$ & Aims & Application & $\begin{array}{l}\text { Used for } \\
\text { (species) }\end{array}$ & Observed benefits \\
\hline Modern health care & 91.8 & $\begin{array}{l}\text { Adapt to } \\
\text { ADOB, } \\
\text { drought \& } \\
\text { frost }\end{array}$ & $\begin{array}{l}\text { Used vaccination, de-worming, spraying and treatments to } \\
\text { prevent and control disease; different vaccination was } \\
\text { given before and after main rainy season, de-worming was } \\
\text { from Sep to Jan; spraying was from Mar to Jun. }\end{array}$ & $\begin{array}{l}\text { All } \\
\text { species }\end{array}$ & $\begin{array}{l}\text { Reduced disease } \\
\text { outbreaks \& animal } \\
\text { mortality rate }\end{array}$ \\
\hline $\begin{array}{l}\text { Traditional health care } \\
\text { herbals }\end{array}$ & 20.2 & $\begin{array}{l}\text { Adapt to } \\
\text { ADOB, } \\
\text { drought \& } \\
\text { frost }\end{array}$ & $\begin{array}{l}\text { Used various animal herbal medicine by traditional healers } \\
\text { and/or themselves }\end{array}$ & $\begin{array}{l}\text { All } \\
\text { species }\end{array}$ & $\begin{array}{l}\text { Heal sick animals with } \\
\text { least costs and reduce } \\
\text { animal mortality rate }\end{array}$ \\
\hline \multicolumn{6}{|l|}{$\begin{array}{l}\text { Natural resource } \\
\text { management }\end{array}$} \\
\hline Water harvesting & 34.5 & $\begin{array}{l}\text { Adapt to } \\
\text { drought }\end{array}$ & $\begin{array}{l}\text { Harvested rainwater and floodwater at individual and } \\
\text { community levels; constructed ponds from Mar to Apr and } \\
\text { collected water from Jul to Aug; used it from Nov to Apr. }\end{array}$ & $\begin{array}{l}\text { All } \\
\text { species }\end{array}$ & $\begin{array}{l}\text { Accessed to water from } \\
\text { three to six months for } \\
\text { drinking and backyard } \\
\text { irrigation }\end{array}$ \\
\hline $\begin{array}{l}\text { Using underground } \\
\text { water }\end{array}$ & 9.5 & $\begin{array}{l}\text { Adapt to } \\
\text { drought }\end{array}$ & $\begin{array}{l}\text { Used underground water using different techniques (i.e. } \\
\text { shallow well, dug well, boreholes) }\end{array}$ & $\begin{array}{l}\text { All } \\
\text { species }\end{array}$ & $\begin{array}{l}\text { Accessed to water } \\
\text { across the year for } \\
\text { drinking }\end{array}$ \\
\hline River diversion & 11.7 & $\begin{array}{l}\text { Adapt to } \\
\text { drought }\end{array}$ & $\begin{array}{l}\text { Diverted rivers or used water pumps to grazing lands and } \\
\text { crop production, which is a good source of feed }\end{array}$ & $\begin{array}{l}\text { Large } \\
\text { ruminant }\end{array}$ & Produce green feed \\
\hline $\begin{array}{l}\text { Soil and water } \\
\text { conservation }\end{array}$ & 70.8 & $\begin{array}{l}\text { Adapt to } \\
\text { drought } \& \\
\text { flood }\end{array}$ & $\begin{array}{l}\text { Constructed different physical structures on farmlands } \\
\text { and protected areas from Mar to May; and then stained by } \\
\text { biological measures from Jul to Aug. This was done by } \\
\text { mobilizing the community for the last eight consecutive } \\
\text { years. }\end{array}$ & $\begin{array}{l}\text { Large } \\
\text { ruminant } \\
\& \text { small } \\
\text { ruminants }\end{array}$ & $\begin{array}{l}\text { Reduced soil erosion \& } \\
\text { floods, improves soil } \\
\text { fertility, volumes of } \\
\text { water bodies, eliminate } \\
\text { water lodging \& } \\
\text { improve crop and fodder } \\
\text { biomass }\end{array}$ \\
\hline Tree plantation & 61.7 & $\begin{array}{l}\text { Adapt to } \\
\text { drought \& } \\
\text { flood }\end{array}$ & $\begin{array}{l}\text { Planted different adaptive trees on private and communal } \\
\text { areas. }\end{array}$ & $\begin{array}{l}\text { All } \\
\text { species }\end{array}$ & $\begin{array}{l}\text { Reduced soil erosion, } \\
\text { improved fodder } \\
\text { biomass, shades; } \\
\text { balance microclimate \& } \\
\text { sourced timber/ } \\
\text { firewood }\end{array}$ \\
\hline
\end{tabular}

springs, streams and rivers, eliminating water lodging and improving crop and fodder production.

Besides, the coverage of forest and vegetation increased and microclimate of the area improved. The result of tree plantation has also served as a source of cash incomes, timbers and firewood for many livestock farmers. Similarly, farmers in north-west Ethiopia adapted to climate change using soil and water conservation through fetching economic, social, ecological and environmental benefits [[10]].

Some livestock farmers also adapted to the effects of droughts using water harvesting. Both rainwater and floodwater were harvested at both individual and community levels. Usually, farmers dig ponds during off-season (i.e. from March to April) to collect water during the main rainy season from July to August. Then, it serves the farmers for three to six months (i.e. from November to April) depending on the size of the pond, the volume of water collected, the severity of the drought and the size of animals. Besides drinking, livestock farmers use the water for irrigation to produce vegetable, maize and forages (i.e. lablab and cowpeas). This water harvesting technique was a low-cost method of supplying and effective utilization of scarce water for smallholder farmers [[41]]. Only few livestock farmers further used underground water $(9.5 \%)$ and river diversion $(11.7 \%)$ as adaption strategies to effects of droughts.

\section{CONCLUSION AND RECOMMENDATION}

For the last ten years, livestock farmers in north Wollo zone experienced with different climatic risks such as drought, flood, frosts and animal disease outbreaks. The trends of their impacts on the farmers have been fluctuating from year to year. The impacts of the risks are also determined by seasons. Their major impacts are massive animal deaths, incurred extra cost of feed and healthcare, unintended sell of animals and draught power loss. Based on farmers' perception, those impact of drought and animal disease outbreak are found at moderate severity level; where frost and flood are at lower level.

To adapt to the risks, livestock farmers use breeding, husbandry and natural resources management strategies in an integrated way. Saving surplus feed, using modern animal healthcare, improving animal housing, conserving soil and water, planting trees and keeping stress resistance breeds are the prominent adaptation strategies in North Wollo zone. Despite this, livestock farmers are still threatened by climatic risks in various ways. Therefore, efforts should be done to support the existing adaptation strategies with science and technologies. More emphasis should be given to work on local breed genetic improvement, stress tolerant forage development, quality feed preservation, crop residue improvement and health management in order to build the resilience capacity of smallholder livestock farmers in North Wollo zone. 


\section{REFERENCES}

[1] Abdela, N., \& Jilo, K. Impact of Climate Change on Livestock Health : A Review. 2016, Glob. Vet, 16(5), pp. 419-424.

[2] Abramovitz, J., Banuri, T., Girot, P. O., Orlando, B., Schneider, N., Spanger-Siegfried, E., Switzer, J., \& Hammill, A. Adapting to climate change: Natural Resource Management and Vulnerability Reduction. 2007, Envi and Urbanization, 19(1), 99.

[3] Abrham Belay, John W Recha, T. W. and J. F. M. Smallholder farmers adaptation to climate change and determinants of their adaptation decisions in the Central Rift Valley of Ethiopia. 2017, Agric.\& Food Security, 6(1), 1-13.

[4] Addisu H., Hailu M., Z. W. Indigenous Chicken Production System and Breeding Practice in North Wollo, Amhara Region, Ethiopia. 2013, Poultry, Fisheries \& Wildlife Sciences, 1(2), pp.1-9.

[5] Alemayehu, K., \& Getu, A. Impacts of climate variability on livestock population dynamics and breed distribution patterns in selected districts of Western. 2016, Animal Genetic Resources, 59, pp.113-121.

[6] ANRS bureau of Agricultural and Rural Development. Annual Report. 2015, unpublished; Bureau of Agricultural and Rural Development, Bahir Dar, Ethiopia.

[7] ANRSLDA (Amhara National Regional State Livestock Development Agency). Growth and Transformation Program -II. 2015, [unpblished]; Bureau of Agricultural and Rural Development, Bahir Dar, Ethiopia.

[8] Asmare, B., \& Meheret, F. Smallholder farmers livestock production on the face of climate change in Bahir Dar, Zuria district, northwestern Ethiopia. 2018, Biodiversitas, 19(6), 2329-2334.

[9] Asnake, B., \& Elias, E. Challenges and extents of Soil and Water Conservation measures in Guba-Lafto Woreda of North Wollo, Ethiopia. 2017, J. Agric Res. Dev., 7(2), 0103-0110.

[10] Asrat Guja, Yoseph Mekasha, H. K. and T. T. Comparative analysis of climate change impact on livestock in relation to biomass base feed availability using standardized precipitation index in south-western Ethiopia. 2018, Int. J. Liv. Prod., 9(7), 184-191.

[11] Asrat, P., \& Simane, B. Farmers' perception of climate change and adaptation strategies in the Dabus watershed, North-West Ethiopia. 2018, Springer, 7(7), 1-13.

[12] Asresie, A. Contribution of Livestock Sector in Ethiopian Economy : A Review. 2015, Adv. Life Scie. Tech (Vol. 29). pp. 79-91.

[13] Atinkut B., \& Mebrat A. Determinants of farmers choice of adaptation to climate variability in Dera woreda, south Gondar zone, Ethiopia. 2016, Envi. Sys. Res., 5(1), 1-8.

[14] Bekele Megersa, Andre Markemann, Ayana Angassa, Joseph O. Ogutu, Hans-Peter Piepho and Zarate, A. V. Livestock Diversification: an Adaptive Strategy to Climate and Rangeland Ecosystem Changes in Southern Ethiopia Livestock Diversification: an Adaptive Strategy to Climate and Rangeland Ecosystem Changes in Southern Ethiopia. 2018, Springer, 42(4), 509-520.

[15] Berhanu, W., \& Beyene, F. Climate variability and household adaptation strategies in southern Ethiopia. 2015, Sustainability (Switzerland), 7(6), 6353-6375.

[16] Birara E. \& Zemen A. Assessment of the Role of Livestock in Ethiopia : A Review. 2016, American-Eurasian J. Scie. Res., 11(5), 405-410.

[17] Carty H. Climate Change and Animal Health: A Concern for Today or Tomorrow?. 2013, FARMING Connect Cyswllt FFERMIO.

[18] CSA (Central Statistical Agency). Agricultural sample survey. 2017, Volume II, report on Livestock and livestock characteristics, Addis Ababa, Ethiopia.

[19] CSA (Central Statistical Agency). Key Findings of the 2014/2015 (2007 E.C.). 2015, Agricultural Sample Surveys, Addis Ababa, Ethiopia.

[20] Chand M.B., Upadhyay B.P., \& M. R. Biogas option for mitigating and adaptation of climate change. 2012, Ren Sym Comp, 1, 5-9.

[21] Deressa T., H. R. and C. C. Perception of and adaptation to climate change by farmers in the Nile basin of Ethiopia. 2010, J. Agric. Scie., 149, 23-31.

[22] FAO. Climate Change and Food Security Climate Change Adaptation and Mitigation in Agriculture. 2012, http://www.fao.org/elearning/Course/FCC/en/pdf/learnernotes0856.pdf

[23] Fikeremaryam Birara, Melaku Berhe, G. G. and D. H. Determinants of adaptation choices to climate change by sheep and goat farmers in Northern Ethiopia: the case of Southern and Central Tigray, Ethiopia. 2016, SpringerPlus, 5(1).
[24] Gebiso, T. Livestock production system characterization in Arsi Zone, Ethiopia. 2018, Int. J. Liv. Prod., 9(9), 238-245.

[25] Gebreselassie A. \& Bekele T. A Review of Ethiopian Agriculture : Roles, Policy and Small-scale Farming Systems. 2012, (D. K. and W. Grech (ed.); Issue Medic 1999). Gloabal Growing Casebook.

[26] Gebreyes M., Tesfaye K., \& Feleke B. Climate change adaptationdisaster risk reduction nexus: case study from Ethiopia. 2017, Int. J. Clim. Change Strategies and Management, 9(6), 829-845.

[27] Gedefaw M, Girma A, Denghua Y, \& Hao W., A. G. Farmer's Perceptions and Adaptation Strategies to Climate Change, Its Determinants and Impacts in Ethiopia: Evidence from Qwara District. 2018, J. Earth Sci. Clim Change, 09(07), 1-8.

[28] Getu, A. The effects of climate change on livestock production, current situation and future consideration. 2015, Int. J. Agric. Sci., 5(3), 494-499.

[29] Gizaw S., Komen H., Hanotte O., Arendonk J. a. M., Van, Kemp S., Haile A., Mwai O. \& Dessie T. Characterization and Conservation of Indigenous Sheep Genetic Resources: a Practical Framework for Developing Countries. 2011, ILRI Research Report No. 27. Nairobi, Kenya, ILRI.

[30] Hailu S. The Impact of Disaster Risk Management Intervention in Humanitarian Programs on Household Food. 2013. https://reliefweb.int/sites/reliefweb.int/files/resources/Hailu - Impact of DRM Interventions in North Wollo Ethiopia.pdf.

[31] Haque, N. Climate Change and Its Impact On Animal Health and Production. 2018, Bull. Env. Pharmacol. Life Sci., 6(4), 177-184.

[32] Herrero M., Addison J., Bedelian C., Carabine E., Havlík P., Henderson B., Steeg J., Van De \& Thornton P. K. Climate change and pastoralism : impacts, consequences and adaptation. 2016, 35(2), 417-433.

[33] Hoffmann I. Climate change and the characterization, breeding and conservation of animal genetic resources. 2010, Animal Genetics, 4l(1), $32-46$.

[34] Hoving I. E., Stienezen M. W. J., Hiemstra S. J., van Dooren H. J., de Buisonjé, F. E. \& Research W. U. R. L. Adaptation of livestock systems to climate change; functions of grassland, breeding, health and housing. 2014, Wageningen, Wageningen UR (University \& Research centre) Livestock Research, Livestock Research Report 793.

[35] IPCC. Climate Change 2007: Impacts, Adaptation and Vulnerability. 2007, Working Group II Contribution to the Fourth Assessment Report of the Intergovernmental Panel on Climate Change.

[36] IPCC. Climate Change 2014: Synthesis Report. 2014, Contribution of Working Groups I, II and III to the Fifth Assessment Report of the Intergovernmental Panel on Climate Change.

[37] Keller M. Climate Risks and Development Projects. 2009, unpublished; reports of Bread for all, Guduru, Oromiya, Ethiopia.

[38] Kuwornu J. K. M., Al-Hassan R. M., Etwire P. M, O.-O. Y. Adaptation Strategies of Smallholder Farmers to Climate Change and Variability: Evidence from Northern Ghana. 2013, Info.Man.\& Business Review, 5(5), 233-239.

[39] Levin, K. A. Study design III: Cross-sectional studies. 2006, EvidenceBased Dentistry, 7(1), 24-25.

[40] Maharjan S. K. Local Adaptation Plan of Action Framework and Process in the Agricultural SEctor in Nepal. 2019, Int. J. Cons. Sci., 10(2), 315364.

[41] Mati, B. M. Soil and Water Conservation Structures for Smallholder Agriculture. 2012, Training manual 5, pp.3-60.

[42] McCornick P. G., Kamara A. B. \& Tadesse G. Integrated water and land management research and capacity building priorities for Ethiopia. 2003, Proceeding a MoWR/EARO/IWMI/ILRI Int. Workshop Held at ILRI, Addis Ababa, Ethiopia, 2-4 Dec, 2002.

[43] Mendelsohn R \& Diana A. Exploring adaptations of climate change in agriculture. 2005, The Potentila of Cross Sectional Analysis ARD, World Bank, 3(1).

[44] Mengistu D. K. Farmers' perception and knowledge on climate change and their coping strategies to the related hazards: case study from Adiha, central Tigray, Ethiopia. 2011. Agricultural Sciences, 02(02), 138-145.

[45] Mimura N., R.S. Pulwarty, D.M. Duc, I. Elshinnawy, M.H. Redsteer, H.Q. Huang, J.N. Nkem, and R. A. S. R. Adaptation Planning and Implementation. 2014, In K. J. M. C.B., V.R. Barros, D.J. Dokken, A. N. L. M.D. Mastrandrea, T.E. Bilir, M. Chatterjee, K.L. Ebi, Y.O. Estrada, R.C. Genova, B. Girma, E.S. Kissel, \& and L. L. W. S. MacCracken, P.R. Mastrandrea (Eds.), Climate Change 2014: Impacts, Adaptation, and Vulnerability. Part A: Global and Sectoral Aspects. Contribution of 
Working Group II to the Fifth Assessment Report of the Intergovernmental Panel on Climate Change (pp. 869-898). Cambridge University Press, Cambridge.

[46] MoFED (Ministry of Finance and Economic Development) Growth and Transformation Plan (2010/11-2014/15). 2010, Unpublished; Addis Ababa, Ethiopia.

[47] Ndamani F., Watanabe T., Ndamani F. \& Watanabe T. Determinants of farmers' adaptation to climate change: A micro level analysis in Ghana. 2016, Sci. Agricola, 73(3), 201-208.

[48] North Wollo zone Livestock and Fishery Development Agency. Annual Report. 2018, unpublished, Woldia, North Wollo zone.

[49] North Wollo Zone Disaster Risk Management Project coordinator (2014). Annual Progress Report. Woldia, North Wollo zone [unpublished].

[50] North Wollo Zone Disaster Risk Management Project coordinator. Annual Progress Report. 2012, Woldia, North Wollo zone [Unpublished].

[51] Portia A. W., Reuben T. L., Isaac Y., \& Godfred K. F. Smallholder farmers experiences of climate variability and change on pineapple production in Ghana: Examining adaptation strategies for improved production. 2018, J. Agric. Ext. \& Rur. Dev., 10(2), 35-43.

[52] Rojas-downing M. M., Nejadhashemi A. P., Harrigan T. \& Woznicki S. A. Climate Risk Management Climate change and livestock: Impacts, adaptation , and mitigation. 2017, Climate Risk Management, 16, 145163.

[53] Ruo G., Brhane Weldegebrial, G. Y. and G. Y. Climate Change Adaptation Practices by Ruminant Livestock Producer of in Hintalo Wajerat District Tigray Regional State, Northern Ethiopia. 2018, Biom. J. Sci. \& Tech. Res., 5(4), 8809-8828.

[54] Shamsul M., Bhuiyan A., Bhuiyan A. K. F. H., Lee J. H. \& Lee S. H. Community based livestock breeding programs in Bangladesh: Present status and challenges. 2017, J. Ani. Breeding and Genomics, 1(2), $77-$ 84.

[55] Solomon T. and Firew T.egene. Impacts of climate change on livestock production and productivity and different adaptation strategies in Ethiopia. 2018, J. Apl. \& Adv. Res., 3(3), 52-58.

[56] Sujakhu N. M., Ranjitkar S., Niraula R. R., Pokharel B. K., Schmidt-Vogt D. \& Xu J. Farmers' Perceptions of and Adaptations to Changing Climate in the Melamchi Valley of Nepal. 2016, Mountain Res. \& Dev., $36(1), 15-30$.

[57] Tadesse, D., Ayalew, W., \& Hegde, B. P. On-farm Phenotypic Characterization of Cattle Genetic Resources in South and North Wollo Zones of Amhara Region, North Eastern Ethiopia. 2008, Ethiopian J. Ani. Prod., 8(1), 22-38.

[58] Tarr, B.. Cold stress in cows. 2007, Ontario. https://doi.org/ISSN 1198$712 \mathrm{X}$

[59] Tembo G., Tembo A., Goma F., Kapekele E. \& Sambo, J. Livelihood activities and the role of livestock in smallholder farming communities of Southern Zambia. 2014, J. Social Sci., Vol. 2, 299-307.

[60] Wolde M., Dessalegn C., Seifu A., Adugnaw T., Christian D., Assefa D., Tigist Y., Tammo S., Essayas K. Sustaining the benefits of soil and water conservation in the highlands of Ethiopia. 2015, technical brief, No. 03.

[61] Tripathi, A., \& Mishra, A. K. Knowledge and passive adaptation to climate change: An example from Indian farmers. 2017, Clim. Risk Man, $16,195-207$.

[62] Veerasamy M. S., Samal L., Haque N., Bagath M., Hyder I., Maurya V. P., Bhatta R., Ravindra J. P., Prasad C. S., \& L. R. Overview on Adaptation, Mitigation and Amelioration Strategies to Improve Livestock Production Under the Changing Climatic Scenario. 2015. In V. Sejian \& J. Gaughan (Eds.), Climate Change Impact on Livestock : Adaptation and Mitigation (pp. 359-398). Springer.

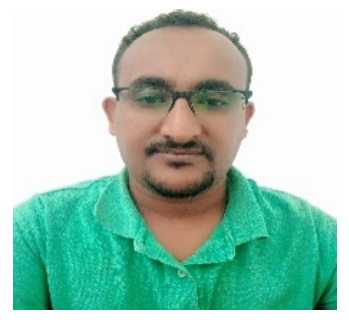

Mr. Habtemariam Assefa is a $\mathrm{PhD}$ student in Agricultural and Rural innovation Studies at Makerere University, Uganda and Agricultural Extension Researcher at Amhara Regional Agricultural Research Institute (ARARI) base in Andasa Livestock Research Center. He was born in July, 19, 1982 in Ethiopia. He has Master Degree in Regional and Local Development Studies from Addis Ababa University in 2010 and his bachelor degree in Agricultural Extension from Haramaya University (formerly Alemaya University) in 2005.

He has accumulated more than 14 years of research experience in socioeconomic and agricultural extension researches while he has been in ARARI and ILRI. He has done various livestock researches in participatory technology evaluation, demonstration and promotions, socioeconomic, adoption, impact and value chain studies, field surveys, coordinating multidiscipline/multi-stakeholders in research programs. He has also developed various research proposals and projects; and has presented his finding at regional, national and international research forums. He is also well experienced in data management, analysis and scientific report writing. Out of his research experience, he has contributed more 16 publications to the body of science through journals, book and research proceedings, as first author and coauthor. Some of them are: Habtemariam Assefa, Tegegni G.Egziabher, Azage Tegegn. Agricultural Knowledge Management: the case of cattle feed improvement in Bure District, West Gojjam, Ethiopia. Journal of Agricultural Extension and Rural Development, Vol. 7(1), pp. 1-7, January, 2015; Habtemariam Assefa and Azage Tegegn. Characterizing Smallholder Dairy Production and their marketing: The implication of enhancing market oriented dairy development in Bure district, Amhara Region, Ethiopia. Journal of Agricultural Economics, Extension and Rural Development: ISSN-2360798X, Vol. 6(3): pp, 728-740, (2018); Zeleke Mekuriaw, Habtemariam Assefa, Azage Tegegne, Dagne Muluneh. Estrus response and fertility of Menz and crossbred ewes to single prostaglandin injection protocol. Journal of Tropical Animal Health and Production, Springer Science, Vol. 47 (7), (2015) etc ... Mr. Habtemariam is also a member of professional society like Ethiopian Society of Animal Science and on the process to be a member of Ethiopia Society of Rural Development and Agricultural Extension. 